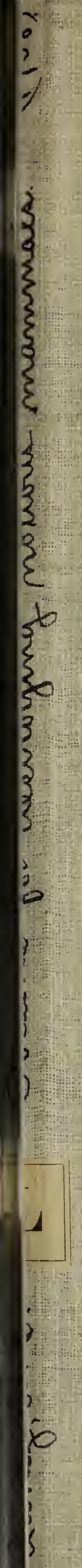




\section{HARVARD UNIVERSITY.}

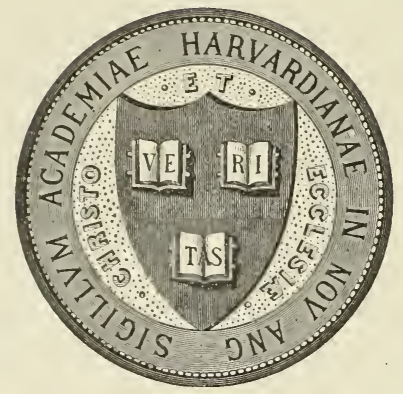

\section{I, I B R A R Y}

OF THE

MUSEUM OF COMPARATIVE ZOÖLOGY.

$$
3 \underline{4,663}
$$

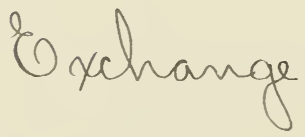

jovember 3, 1909 . 
Nox $3 \quad 19$

34663

\section{USE OF POISONS FOR DESTROYING NOXIOUS MAMMALS.}

By

DAVID E. LANTZ,

Assistant, Biological Survey.

[Reprint from Yearbook of Department of Agriculture for 1908.]

88928-09

WASHINGTON : GOVERNMENT PRINTING OFFICE : 1808

$3 \mathrm{~m}$ 


$$
\begin{aligned}
& +17=101
\end{aligned}
$$

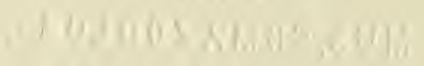

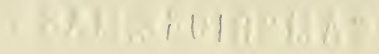




\section{CONTENTS.}

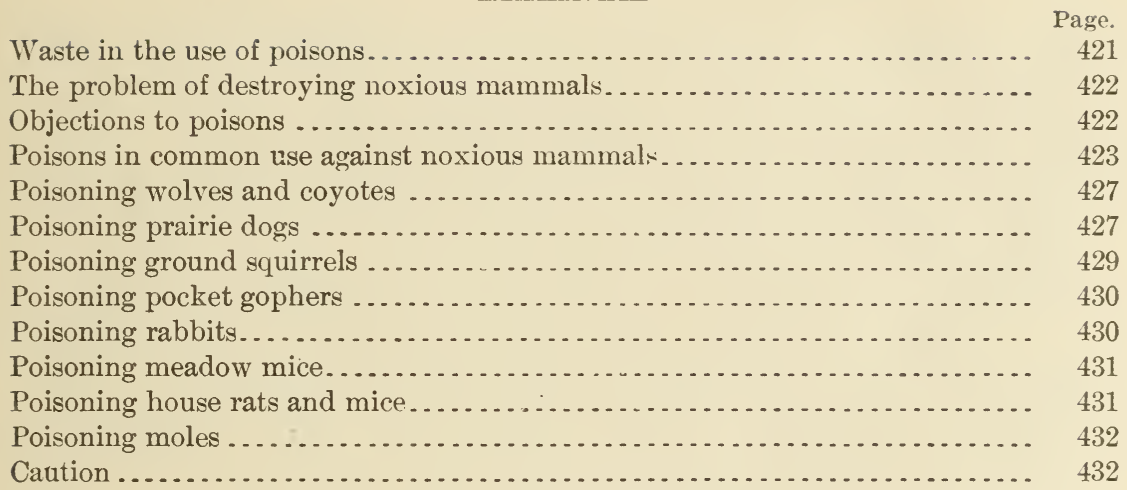





\title{
USE OF POISONS FOR DESTROYING NOXIOUS MAMMAS.
}

\author{
By David E. Lantz, \\ Assistant, Biological survey.
}

WASTE IN THE USE OF POISONS.

Poisons are so extensively used in the United States for the destruction of noxious animals that the commerce in them is enormous. Almost all druggists have a considerable trade in substances intended to rid field, garden, orchard, or buildings of pests that destroy crops or other property. These poisons are sold in three forms-proprietary preparations, raw materials, and preparations mixed by the druggist ready for use.

Whatever the form, the purchaser often pays an excessive price for the poison, and then frequently wastes much because of lack of knowledge of how best to use it. Since in the West the people of a single county sometimes expend $\$ 25,000$ to $\$ 30,000$ a year for poisons for destroying rodent pests, and since insecticides and other poisons for the entire country cost many millions of dollars annually, the saving of waste in these items is important. At present fully half the expenditure in the United States for rodent poisons is wasted.

Probably the buyer of proprietary poisons has the greatest cause for complaint. Often 1 or 2 cents' worth of material is retailed at from 25 cents to a dollar. The difference between the cost of the material and the selling price represents the manufacturer's profit and the retailer's commission. Large returns enable proprietors to spend much money in advertising or otherwise exploiting their wares, some of which have no merit. But a man does not always complain of excessive cost if the poison proves efficacious. It is when little or no results follow its use that he considers himself defrauded. In reality he is cheated when he pays an unreasonably large price for the manufactured product, because the raw materials are cheap, and directions for their combination and use are now available.

The formulas for the common insecticides are the result of longcontinued experiment by expert entomologists and orchardists. They' have become standard by reason of long and successful use, and wellinformed farmers are now comparatively safe from the impositions of venders of so-called insecticides. But until recently the destruction of noxious mammals has received less attention from experts than 
the destruction of insect pests, and the buyer of poisons for mammals has had to depend upon scattered information or personal experiment.

One of the duties of the Biological Survey is to ascertain by experiment the most effective and economical methods of combating noxious mammals and birds. The present article aims to bring together the best formulas and methods, and thus to enable farmers, ranchmen, and other's to save time, labor, and money.

\section{THE PROBLEM OF DESTROYING NOXIOUS MAMMALS.}

The destruction of noxious mammals is a more complicated problem than that of insect destruction. The farmer who fights these higher forms deals with instincts and intelligence well adapted to cope with his own in the struggle for existence. It is not enough that he place poisoned food or traps in the way of the creatures he desires to destroy; he must make the baits attractive and allay the natural suspicion of the animals by ridding traps of all suggestion of their real nature. He must know the traits of the animals and take advantage of any habit that will enable him to circumvent and destroy them. With such knowledge and the aid of plain, practical directions for carrying on his offensive operations he can in most cases do far more effective work with poisons than with traps, guns, and similar devices. The usefulness of traps, however, should not be overlooked, especially since they can be employed under conditions which preclude the use of poisons; but when large areas are involved and crops are threatened with immediate ruin, swifter methods are needed. Sometimes also the trap is a useful secondary agent for completing the work after the use of poisons.

OBJECTIONS TO POISONS.

It has been urged against poisons that their use is attended by danger, not only to domestic animals but to human beings; if carelessness attends their handling, this is undoubtedly true. In Great Britain the laying of poisons in the open is forbidden under heary penalties, and the use of poisons for mammals is restricted to ricks, drains, and other places out of the reach of domestic animals. In this country nearly all the States have statutes regulating the sale of poisons, and sereral of them forbid the laying of poisoned baits for predatory animals on lands not owned by the person who puts out the poison. A few States require posting of special notices in the neighborhood when poisons are laid for wolves or other wild animals. The poisoning of predatory dogs is prohibited in some States and specifically permitted in a few. In general, it may be stated that in the West, where wolves, ground squirrels, prairie dogs, gophers, and similar pests abound, few laws restricting the use of 
poisons exist. It is well, however, for anyone desiring to poison pests to first inform himself thoroughly as to the statutes of his State on the subject.

Another objection that has been urged to the destruction of mammal pests by poisons is that their use is inhuman, entailing much suffering upon the victims. The same objection holds to even greater degree against trapping, shooting, and other methods of taking life.

\section{POISONS IN COMMON USE AGAINST NOXIOUS MAMMALS.}

The poisons most commonly used to destroy mammal pests in America are phosphorus, arsenic, and strychnine. Nearly all the proprietary poisons on the market have phosphorus or arsenic as a base. Other substances that have been recommended are barium carbonate, potassium cyanid, corrosive sublimate, nux vomica, cicuta, and common squills.

PHOSPIIORUS.

Yellow phosphorus seems to be the poison most used for the destruction of rodents. It is an irritant poison, usually slow, though quite variable in rapidity of action, but eventually destroying the life of any animal that eats it. One-fourth of a grain is a dangerous dose for a person, and in one instance a much smaller quantity proved fatal. Used medicinally, it is given in doses of one one-thousandth to one-thirtieth of a grain. Commercial or yellow phosphorus is usually kept under water in the form of waxy, translucent sticks. It is soluble in 4 parts of carbon bisulphid. Its efficiency as a poison depends on the fineness of division. That prepared and mixed by machinery is usually better than poorly mixed, homemade preparations. The fineness of division is accomplished by first dissolving the phosphorus in carbon bisulphid, after which the solution is mixed with any suitable medium. Phosphorus rat and roach pastes usually contain from 1 to 2 per cent of phosphorus in a medium of flour or meal and glucose. A popular English rat paste has 4 per cent of phosphorus.

There are several serious objections to the use of phosphorus. The first is that its slow, irritant action entails much unnecessary suffering. While the right to take the life of noxious animals is generally conceded, it should be done without needless torture.

The danger to person and clothing in handling yellow phosphorus should be generally known. This substance is kept and cut under water and should not be touched with the hands. A nearly saturated solution in carbon bisulphid has been known to burst into flame while being carried, setting fire to everything which it touched. ${ }^{a}$

${ }^{a}$ Essence of turpentine is said to be a positive antidote for phosphorus poison and a cure for external burns by this element. 
The chief objection to the use of phosphorus is the danger of serious conflagrations. In the West, where phosphorus is extensively used for killing ground squirrels, it has caused fires which destroyed entire fields of ripe wheat and barley and buildings in which prepared phosphorus was stored. Some hazard attends the use even of carefully prepared phosphorus pastes. Experiments with a commercial paste containing 1.6 per cent of phosphorus showed that it could not be ignited either by contact with flame or by friction; but when stirred after a few hour's' exposure to the sun, it burst into flame. Another sample of paste, containing less than 1 per cent of phosphorus, was subjected to the same tests but could not be ignited. It was then left out of doors over night, and rain washed out part of the glucose. The residue, dried by exposure to sun and wind, soon charred and burned through the paper on which it lay.

ARSENIC.

The qualities of arsenic as a poison are pretty generally understood. In the form of Paris green or London purple it is widely employed as an insecticide. It is comparatively cheap, but is by no means as deadly as phosphorus or strychnine. The smallest quantity known to have been fatal to a human being is 2.5 grains. Ordinarily 2 grains would be a dangerous dose for an adult; but much larger quantities are known to have been taken by persons who had become arsenic eaters. Farriers often give a horse a dose of 20 grains without bad results. Its action on rodents is exceedingly variable, and there is ample proof that rats after taking small doses frequently become entirely immune to its further effects.

White arsenic is sparingly soluble in water, and the crystallized form is less soluble than the amorphous. Both forms are acid to test paper, and to some extent acidulate food with which they are mixed. Experience seems to prove that the souring of baits is often sufficient to keep rodents from eating them. This circumstance and the uncertainty of results even when baits are eaten are the chief objections to arsenic. As an alternative, when the bitterness of strychnine prevents baits from being eaten, arsenic is a useful poison.

STRYCHNINE.

Strychnine is one of four alkaloids obtained from nux vomica, the seed of a tree known to botanists as Strychnos nux vomica. The chief supply comes from the Malabar Coast, India. Strychnine occurs also in the bark of the same tree, and probably in all plants of the genus Strychnos.

The strychnine of commerce consists of the alkaloid in colorless crystals or white powder, and of several salts, chiefly the sulphate and the nitrate, in needle-like crystals or powder. The alkaloid is 
very slightly soluble in water alone, but if an acid be added it dissolves readily. It is soluble also in about six parts of chloroform. The two salts named are freely soluble in 50 parts of cold water and in two or three parts of boiling water. On account of its solubility the sulphate is the most convenient for poisoning rodents, and it should always be used in preference to the alkaloid. It is usually slightly cheaper and is equally deadly.

Strychnine is exceedingly bitter, and this bitterness is a partial safeguard against the accidental swallowing of the poison. It acts upon the nervous system of animals, producing tetanus, convulsions, and speedy death. The least dose known to have been fatal to a human being is half a grain, but a quarter of a grain is regarded as a dangerous dose. The medicinal dose is one one-hundredth to onetwentieth of a grain.

The bitterness of strychnine sometimes causes baits to be rejected by animals. To counteract this, sugar is generally, used. The same object is sometimes accomplished by mixing powdered strychnine with honey or with its own weight of commercial saccharine. For poisoning rabbits and field mice, which are accustomed to bitter foods, no sweetening is required, and it is probable that the bitterness of strychnine is no obstacle to poisoning certain other rodents.

As a poison for noxious animals strychnine has several advantages over the others commonly in use. It kills quickly, without the long tortures of corrosive poisons. In spite of its bitterness, baits containing it are rejected less often than those containing arsenic. If strychnine is properly labeled and kept from children, it is less dangerous to have on the premises than most other poisons. Should strychnine be accidentally swallowed by an adult, antidotes are usually available, and by prompt action a fatal result may be prevented. $^{a}$ Finally, considering both cost and efficiency, strychnine is an economical poison.

Comparative cost of strychnine and arsenic.-The cheapness of arsenic leads many to select it for poisoning noxious mammals. But experiments by the Biological Survey show that strychnine, all things considered, is a cheaper poison than arsenic. Strychnia sulphate may be purchased in bulk at about 75 cents an ounce; white arsenic costs about 15 cents a pound. An ounce of strychnine will

${ }^{a}$ In case of poisoning by strychnine an emetic should be promptly giren-a teaspoonful of mustard in a glass of water (warm, if a vailable). Another excellent emetic is zinc sulphate (10 to 60 grains in tepid water) or apomorphine (4 drops by hypodermic injection). A stomach pump can not be used after the first few minutes. As soon as the emetic has acted, the patient should be put slightly under the influence of chloroform or ether, and kept so for several hours. He should be kept in a darkened room and away from noise of all kinds. Further treatment may be left to the physician, who should be summoned as soon as the poisoning is discovered. 
thoroughly poison 60 pounds of wheat intended for field mice; a pound of arsenic will poison only 10 or 12 pounds of the grain for the same purpose. The cost of preparing the 60 pounds of wheat, therefore, will be about the same with either poison; but more of that containing arsenic is required to kill. Actual field experiments clearly demonstrated the advantages of strychnine. The baits containing strychnine were eaten freely and many dead mice were found, while on the areas treated with arsenic little of the wheat was eaten and dead mice were few. Experiments show that an ounce of strychnine, if properly distributed, and if none is wasted, is enough to kill t,500 prairie dogs or large ground squirrels or 9,000 field mice.

OTHER POISONS.

Baridur carbonate.-As sold commercially, this is a dense, heavy white powder, insoluble in water but dissolving in the presence of several of the common acids. It is a rather cheap mineral poison without taste or smell. For this reason it has been recommended for destroying rats and mice. It is poisonous to larger animals when taken in considerable quantities, and in one case of human poisoning 60 grains of the salt proved fatal. Its action is corrosive and very slow.

Potassiun Cranid.-This intensely poisonous substance has been employed for destroying prairie dogs in the West, but usually in combination with strychnine. Although cheap, the fact that in contact with the soil and atmosphere it rapidly decomposes and loses its poisonous qualities impairs its usefulness. It has been found too that dogs, when given doses of 2 or 4 grains of potassium cyanid, vomit the poison and recover.

Corrostre sublmate.-Corrosive sublimate, or mercuric chlorid, of commerce occurs in heavy colorless masses, which dissolve in 16 parts of cold water and 3 parts of boiling water. $\mathrm{A}$ dose as small as 3 gains has been known to be fatal to man. Its corrosive action on the digestive tract is rapid, and somewhat like that of carbolic acid, but death results usually from exhaustion. Although this poison has often been recommended for rodents, the burning sensation in the mouth and the constriction of the throat it causes preclude its employment.

Nux rourics.-The nux vomica of commerce, extensively used in medicine, is largely employed in the Old World for poisoning rodents. It contains from 2 to 5 per cent of poisonous alkaloids, mainly brucine and strychnine, but the proportions of each vary so greatly that the strength of the poison is uncertain, and it is better to use the purer strychnine instead. The baits can then be made of definite strength and the poison economically applied. 
CicuTA AND SQUILL. - These two plants have been recommended for destroying rats and mice, and published formularies contain directions for preparing the poisons. The first is Cicuta virosu or $C$. maculata, known as water hemlock, a common marsh plant, the roots of which contain a very active poisonous principle known as cicutoxin. This produces tetanic convulsions and death in animals. The bulbs of the common squill or sea onion contain scillitin, a poisonous glucoside which dissolves in alcohol or ether. This poison is sometimes used in connection with barium carbonate, the squill, it is said, being used chiefly to attract rats or mice to the bait. The writer has not yet tested the efficiency of these poisons.

\section{POISONING VOLVES AND COYOTES.}

Passing from the general consideration of poisons to their practical use by the farmer and stockman for the protection of his property against pests, it may be stated that strychnine is the most effective poison known for wolves. The strychnia sulphate is to be preferred on account of its quicker action. The proper dose for a wolf is 4 grains; for a coyote, 2 grains. The common 3 -grain gelatin capsules of the drug stores, if well filled, will hold 4 grains of strychnine. The 2-grain capsule should be used for coyotes. Fill, cap, and carefully wipe each capsule to remove every trace of the drug from the outside. Insert it into a piece of beef suet the size of a walnut and close the cavity. The baits should be carried in a can or pail and not handled except with gloved hands or forceps. They should be dropped from horseback along trails followed regularly by wolves or along an artificial trail made by dragging an old bone or piece of hide well saturated with the fetid scent described in Circular 63 of the Biological Survey, which should be consulted for more detailed directions for destroying wolves. These baits are very effective when placed around or partly under a carcass on which wolves or coyotes are feeding.

POISONING PRAIRIE DOGS.

Poison and fumigation with carbon bisulphid are the only means that have proved successful in destroying prairie dogs over large areas. The cost of poisoning is less than half the cost of fumigation. The area should first be gone over with poison and the bulk of the animals thus destroyed. The few that escape may then be located in their burrows and destroyed with carbon bisulphid.

Wheat treated with strychnine has proved an economical and efficient poison, but is objectionable because it kills numerous valuable birds. Rolled grain and meal are less likely to be eaten by 
birds, particularly if carefully placed close to the mouths of the burrows. Is a medium for conveying the poison there is little doubt that alfalfa, either green or dry, will prove equally or even more successful, and it has the advantage that it is not eaten by birds.

One and a half ounces of strychnia sulphate is enough to prepare a bushel of wheat. Dissolve the strychnine in a quart of boiling water and add a quart or more of thick sugar sirup. Pour this mixture orer the wheat in a clean metal vessel and stir until all the wheat is wet. Stir in corn meal to take up any surplus moisture, if the poison is to be used immediately, or add more water and leave the wheat to absorb the strychnine orer night. Many experienced persons prefer the latter plan, but the writer has been equally successful with both. About a teaspoonful of the poisoned wheat is placed at the mouth of each occupied burrow. It is important to choose a time when the animals are both active and hungry, preferably in winter or early spring.

The Kansas formula.-A few years ago the State of Kansas carried on extensive operations against prairie dogs, destroying them almost completely over nearly $2,000,000$ acres of thickly infested land. 'The poison was prepared at the State agricultural college experiment station, and for more than three years the writer had charge of its preparation and distribution. It was sold to townships and individuals at cost, or the formula for preparing it was given to citizens of the State who asked for it. The formula was adapted from one patented by David IV. Staples, formerly of Quanah, Tex. ${ }^{a}$ The State purchased the right to use the poison, but the writer found the formula impractical for large operations and it was modified into the following:

For 1 gallon poisoned sirup, use-

4 ounces powdered strychnia sulphate;

4 ounces potassium cyanid;

4 ounces green coffee;

6 ounces alcohol;

4 eggs (whites only);

$\frac{1}{2}$ gallon thick sugar sirup.

Preparation.-Mix the coffee and whites of eggs, and let the mixture stand over night. Dissolve the cyanid of potassium in a little less than a quart of hot water, and let it cool before using. Prepare the sugar sirup previously, so that it is not hot when used. Pour the cyanid of potassium solution over the coffee-and-egg mixture, stir, and then strain into the mixing ressel through a sieve fine enough to hold the coffee. which is rejected. Add the sugar sirup and stir thoroughly. Dissolve the strychnia in a little less than a quart of boiling water. Pour the alcohol into this solution and stir. Then add the mixture of strychnine, alcohol, and water to the contents of the mixing vessel and stir thoroughly.

${ }^{a}$ Patent No. 456602, issued July 28, 1891. Expired July 2S, 190 S. 
The strychnine will be precipitated by the cyanid, and when the poison is placed in a can and allowed to stand will settle at the bottom. The poison should be kept closely corked until used.

A gallon of this poisoned sirup is enough to poison two bushels of wheat. Before it is mixed with the wheat it should be thoroughly stirred or shaken, and a few pounds of corn meal added to make the sirup adhere to the grain. This preparation may be used inmediately. Another way is to add more water and leave the wheat over night to absorb the strychnine.

The potassium cyanid in this formula makes the poison a quick killer when first put out. The quantity of strychnine is probably somewhat in excess of actual requirements.

Green alfalfa or alfalfa hay for poisoning prairie dogs should be chopped into short lengths and sprinkled with strychnine water or sirup until thoroughly wet. A large metal washtub should be used as a mixing ressel. An ounce of strychnia sulphate dissolved in a half gallon of water will prepare 30 pounds of green alfalfa; or the same quantity of strychnine dissolved in 3 or 4 gallons of water will prepare 20 pounds of alfalfa hay.

\section{POISONING GROUND SQUIRRELS.}

Ground squirrels are a serious pest in many parts of the West. The larger species are usually more difficult to poison than the smaller ones; but as they ordinarily eat more food, the difference in the formulas is less than one might expect. For the smaller ground squirrels, use-

1 ounce strychnia sulphate,

35 pounds clean wheat,

2 gallons water.

Dissolve the strychnine in the water in a large mixing vessel. Then pour in the wheat and allow all to simmer for an hour, the vessel being corered. Stir occasionally. The water will probably be entirely absorbed by the grain, but if not, a little corn meal will take up the extra moisture. If preferred, the strychnine may first be dissolved in a pint of boiling water, the ingredients then mixed in a large vessel, and all left over night to absorb the poison. Distribute the poisoned wheat, a half teaspoonful at a place, at the mouth of the squirrel burrows. Do not scatter broadcast on account of the danger of killing birds.

For the larger ground squirrels reduce the quantity of wheat in the above to 25 pounds and the water in proportion. Experiments in California in destroying the digger ground squirrel (Citellus beecheyi) with pieces of sugar beets into which crystals of strychnia sulphate had been inserted with a knife gave good results. 
POISONING POCKET GOPHERS.

The several species of pocket gophers in the United States differ considerably, but they are much alike in their destructive habits and are a pest wherever they occur in cultivated lands.

The pocket gophers of the Mississippi Valley and the southern States east of the Mississippi belong to the genus Geomys, and are readily poisoned with strychnine. The writer has had excellent success in destroying them with various baits in the late fall and early winter and reasonably good results at other seasons. Crystals of strychnine may be inserted into pieces of potato, carrot, or sweet potato, or in raisins, and the baits placed in the tunnels several feet from the fresh mounds. If placed in the laterals near the mounds they are likely to be pushed out by the animals in bringing out soil and so not found. An instrument consisting of a spade handle shod with a metal point and having a metal bar for the foot about 15 inches from the point is admirably adapted to making openings into the tumnels into which the baits may be dropped. The holes need not be closed.

With the instrument described it is possible for one man in a day to distribute gopher poison on 30 to 40 acres of badly infested meadow or alfalfa land. A sharp-pointed stick may be substituted for the spade handle, but it can not be operated successfully in any but loose soils.

Corn soaked in strychnine sirup prepared as recommended for poisoning prairie dogs is an excellent bait for pocket gophers. A few kernels are dropped into holes made in runways as described above.

(For methods of trapping gophers, see revised edition of Circular 52 of the Biological Survey, "Directions for Destroying Pocket Gophers," 1908.).

\section{POISONING RABBITS.}

Rabbits, especially jack rabbits, are pest's in many parts of the West. Winter has proved the best time for poisoning them. In summer the baits are often eaten by grasshoppers, and because of the abundance of green foods, are much less likely to be taken by rabbits.

Pieces of apple, carrot, sweet potato, or melon rind are favorite baits for rabbits. Crystals of strychnia sulphate are inserted in them and they are left along rabbit runs, either on the ground or elevated on short sticks. Artificial runs may be made in orchards with a drag or one-horse scraper. Another excellent bait is oatmeal soaked in a sweeténed solution of strychnine. Bran or chop, prepared with arsenic for poisoning grasshoppers, has sometimes proved effective for rabbits. 
In winter rabbits may be poisoned with alfalfa hay prepared by the formula for poisoning prairie dogs, or by baiting with twigs cut from apple trees and dipped in a rather thick solution of strychnine and sugar. Both baits have the advantage of not endangering birds, but the poisoned alfalfa should be fed in inclosures from which live stock is excluded. At the same time the rabbits must be carefully fenced away from haystacks, or they may not eat the poisoned bait.

\section{POISONING MEADOW MICE.}

The most effective poison for the short-tailed field mice is strychnine. In the recent outbreak of these pests in Nevada, the best baits proved to be alfalfa and crushed wheat.

An ounce of strychnia sulphate dissolved in 5 or 6 gallons of water will effectually prepare 30 pounds of chopped dry alfalfa hay; or, with $1 \frac{1}{2}$ gallons of water, will prepare 45 pounds of green alfalfa cut into short lengths. The poisoned food is distributed near or in the mouth of burrows, a small pinch at a place, especially in cold weather, when the animals do not feed in the open. Green alfalfa bait should not be put out when the sun is hot.

In the absence of alfalfa, crushed wheat is an excellent bait. An ounce of strychnia sulphate in 2 gallons of water will poison 60 pounds of crushed wheat. The prepared wheat is distributed in the mouse runs near burrows, very small quantities at a place. No more food than the mice can eat should be put out, especially as the wheat endangers a number of kinds of birds.

Mice in orchards and other places where they occur in normal numbers may be destroyed by feeding the prepared baits under shelters where birds will not find them. Piles of brush, wide boards, old tin cans with the ends crushed inward, and drain pipes have all been recommended as coverings for the poisoned food. Twigs of apple trees poisoned as for rabbits have also given excellent results with field mice without danger to other animals or birds.

\section{POISONING HOUSE RATS AND MICE.}

It is usually undesirable to poison rats or mice in occupied dwellings, since, notwithstanding statements to the contrary, no poison is known which when eaten will prevent decomposition of the animal's body. Hence traps are the chief reliance of the householder to keep his home free from these rodents. The more slowly acting poisons have sometimes been recommended as permitting the rats time to leave houses before dying. Barium carbonate most nearly fulfills this requirement, but if rats eat much of the poison they frequently die on the premises. The powder may be spread or sprinkled upon small pieces of buttered bread; or one part by bulk of barium car- 
bonate may be mixed with eight parts of rolled oats, and enough water added to wet the mixture and make a thick dough.

For poisoning rats in fields or in places where the lives of domestic animals are not endangered, grain soaked in strychnine sirup is successful. A good plan is to bait the animals for several nights with unpoisoned grain, until they are accustomed to feeding at a particular place. Then feed nothing or very little for a single night, and the next follow with a liberal quantity of poisoned grain.

The common brown rat becomes wary and suspicious with age and experience, and is then difficult to trap or to poison. Care to avoid handling baits or traps and skill in choosing localities and otherwise allaying suspicion are essential to success with old rats. The young are no more difficult to trap or poison than are mice.

\section{POISONING MOLES.}

Moles are not vegetarians, but feed almost exclusively on earthworms and insects. They do much good"by destroying white grubs, the larve of various species of June bugs, or May beetles. They do no harm except to lawns; and the actual injury is slight, except in times of drought, when the grass dies along their tunnels. Rolling is usually a remedy for the injury.

The disrepute attaching to moles as destroyers of crops or plants is due largely to a misapprehension of facts. The pine mouse and other species of meadow mice habitually utilize the mole runs and destroy potatoes and other roots and regetables, while the innocent mole bears the blame. The mice may be readily killed by placing poisoned grain in the mole runs.

It is claimed that moles may be poisoned by small bits of meat into which strychnine has been inserted, or by earthworms cut and sprinkled with powdered strychnine. Experiments by the writer have given negative results. Experiments with the soft, milky kernels of fresh green sweet corn soaked in strychnine sirup and placed in the mole's tunnels were more successful, several dead moles having been dug out by dogs within short distances of the places where the poison had been inserted.

\section{CALTION.}

All operations with poisons for noxious mammals should be conducted with every safeguard against accidents to persons, domestic animals, and game. Wisely used and carefully handled, poisons need not endanger lives other than those aimed at. Ordinarily, beneficial birds have suffered much from squirrel and prairie-dog poisons, especially in winter. Experience has taught the writer that during poisoning operations on the plains, if unpoisoned grain is scattered freely in the vicinity of watering places, the birds will remain there and few of them will find the poisoned grain intended for the rodents. 
